\title{
BIBLIOGRAPHY OF THE DEPARTMENT FOR THEORETICAL PHYSICS, UNIVERSITY OF LVIV, IN 1914-1939
}

\author{
Andrij Rovenchak \\ Department for Theoretical Physics, Ivan Franko National University of Lviv, \\ 12, Drahomanov St., Lviv, UA-79005, Ukraine, tel.: +38032 2614443, e-mail: andrij.rovenchak@gmail.com
}

(Received May 14, 2013; in final form - September 20, 2013)

\begin{abstract}
The period of 1914-1939 in the history of the Department for Theoretical Physics, University of Lviv, is analyzed in the paper. A complete to date known bibliography of the staff is listed. Brief biographical accounts of persons affiliated at the Department during these years are given.

Key words: University of Lviv, theoretical physics, bibliography.

PACS number(s): 01.30.Tt, 01.60. $+\mathrm{q}$
\end{abstract}

To the 140th anniversary of the Department for Theoretical Physics and the 60th anniversary of the Faculty of Physics, University of Lviv

\section{INTRODUCTION}

University of Lviv, founded in 1661, is one of the oldest in Eastern Europe. It is located in the city of Lviv (known also as Leopolis in Latin, Lwów in Polish, Lemberg in German, etc.) in the Western part of Ukraine. Physics, as a part of philosophy, has been taught at the University nearly from the beginning. The first chair (Lehrkanzel) of physics was created in the 1770s and occupied by Franz Güssmann $(* 1741-\dagger 1806)$, who moved in 1787 to the University of Vienna. The chair was later held by: Ignác Martinovics $(* 1755$ - †1795, chairman in 1783-91), Anton Hiltenbrand (*1721 - †1798, chairman in 1792-94), Ivan (Johannes, Jan) Zemantsek (*1759 - †1825, chairman in 1794-1805), Anton Gloisner $*^{*} 1782$ - †1855, chairman in 1805-23), August Kunzek (*1795 - †1865, chairman in 1824-48), Aleksander Zawadzki (*1798 - †1868, acting chairman in 1848-52), Viktor Pierre $(* 1819$ - †1886, chairman in 1853-57), Wojciech (Adalbert) Urbański $(* 1820-\dagger 1903$, chairman in 1857-59), and Alois Handl (*1837 - †1915, chairman in 1859-72). This information was compiled from several sources, including [1-4].

In 1873, a separate professorship of theoretical (mathematical) physics - and thus the respective chair - was created in the University of Lviv, following general trends in the development of physics at that time [5]. The first professor was Oskar Fabian $(* 1846$ - †1899), who was succeeded in this position by Marian Smoluchowski (*1872 - †1917), a world-famous physicist, in 1899. Lviv period was most productive in Marian Smoluchowski's scientific work [6]. In spring 1913 he moved to Kraków and the position of a professor of theoretical physics was occupied by Konstanty Zakrzewski in September, 1913. Twenty-five years of a rather complicated period, starting from the World War I and followed by the Interbellum till September, 1939, are described in this work.

In different kinds of documents and publications from the respective period this university unit is referred to in a number of different ways: seminarjum, zaktad, katedra in Polish, or Institut in German. While katedra was not an official name for the administrative unit, it can be found in some paperwork (mostly in applications for a position at the University). The term Division would fit best for zaktad, the most typical reference for this university unit. In this work, according to the modern trend, the term Department is used.

\section{PERSONALIA}

For the period of 1914-1939, eleven persons were affiliated to the Department for Theoretical Physics of the University of Lviv. The list of such persons, with details on dates of their affiliation, is essential for the compilation of the bibliography of the Department. Even if a person did not publish any known work, some publications can be discovered in future and such a list will make the attribution easier.

The chair was held by four professors: Konstanty Zakrzewski (1913-18); Stanisław Loria (1919-27), acting as a professor of theoretical physics till 1930; Szczepan Szczeniowski (1931-36); Wojciech Rubinowicz (1937-44). Their brief biographic accounts are given below. They were compiled both from papers [7-12] and from archival data [13-15].

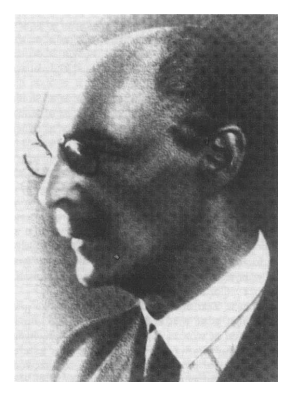

Konstanty ZAKRZEWSKI (*14.I.1876 in Warsaw - †19.I.1948 in Kraków). He graduated from the Jagiellonian University in 1900. His doctoral degree was obtained from the Jagiellonian University in 1900 for the thesis $O$ sile elektromotorycznej wywotanej przez ruch cieczy $w$ posrebrzonej rurze /On the electromotive force induced by the motion of the liquid in a silvered tube/, and the habilitation was awarded in 1908 based on the work entitled Teorya elektronowa metali [Electronic theory of metals]. Zakrzewski worked at physical laboratories in 
Göttingen and Leiden, was an assistant of Heike Kamerlingh Onnes. In 1903 Zakrzewski returned to Kraków, where he worked first as a privatdozent and later as an extraordinary professor of experimental physics in 1908 13. Since September, 1913 till April, 1918 Konstanty Zakrzewski was an ordinary professor of theoretical physics at the University of Lviv. Afterwards, he returned to the Jagiellonian University in Kraków as an ordinary professor of experimental physics. The scientific interests of Prof. Zakrzewski included electronic theory of metals and their optical properties. He designed a new type of an elliptic analyzer to define optical constants of metals. The Commission of Stations for Cosmic Ray Studies of the Polish Academy of Sciences was initiated by Prof. Zakrzewski in 1947. He is a founder of the scientific school of physics of dielectrics in Poland. Konstanty Zakrzewski authored about thirty scientific works. He was a member of the Polish Academy of Arts and Sciences (Polish: Akademja Umiejętności; correspondent since 1920 and full member since 1932).

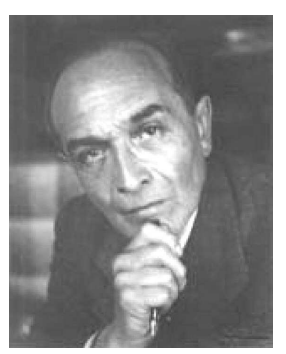

Stanisław LORIA $(* 18.1 .1883$ in Warsaw - †08.VIII.1958 in London). He graduated from the Jagiellonian University in 1905. In 1905-07 he worked as a demonstrator at the Department for Experimental Physics at the Jagiellonian University. His doctoral degree was obtained from the Jagiellonian University in 1907 for the thesis Untersuchungen über das seitliche Sehen. In 1907-10 he visited Wrocław, Berlin, London, and Vienna universities, as well as physical laboratories in Amsterdam, Zürich, and Manchester. In 1910 Stanisław Loria became an assitant of the Physical Institute, and in 1911 habilitated as a privatdozent of experimental physics at the Jagiellonian University for the work $O$ magneto-optycznym zjawisku Kerra $w$ ferromagnetycznych zwiazkach $i$ stopach /On the magneto-optical Kerr phenomenon in ferromagnetic compounds and alloys]. Since April, 1919 till July, 1927 he worked as a professor of theoretical physics (remaining an acting professor till the end of 1930), and then till 1941 as a professor of experimental physics at the University of Lviv. In 1923-25 S. Loria stayed in the USA working at the Norman Bridge Laboratory of Physics, California Institute of Technology in Pasadena. In 1944-51 he was a professor at the University of Wrocław, and in 1951-58 worked at the University of Poznań. Diverse scientific interests of Prof. Loria included: optics, magneto-optic Kerr effect, radioactivity, diffraction of electric waves, experimental psychology, etc. He authored about thirty scientific publications.

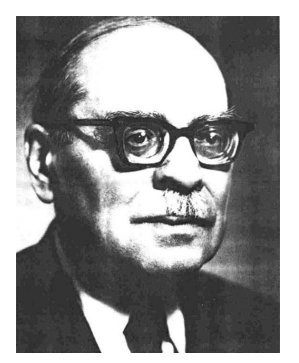

Szczepan Eugeniusz SZCZENIOWSKI $(* 26$.XII.1898 in Warsaw - †18.II.1979 in Warsaw). He graduated from the Warsaw University in 1920 , then continued his studies in 1921-26 and worked in 192630 at the Institute for Experimental Physics of the Warsaw University. His doctoral thesis was $O$ wydajności fluorescencji roztworów /On the fluorescence efficiency of solutions] (1927), habilitation was awarded in 1930. Since January, 1931 till December 1936 Szczepan Szczeniowski headed the Department for Theoretical Physics of the University of Lviv, first as an acting professor in 1931-33, then as an extraordinary professor in 1933-36. In 1937-39 he was a professor of theoretical physics at the University of Vilnius, then in 1945-63 worked at the University of Poznań; in 1957-79 was a professor at the Institute of Physics of the Warsaw University of Technology heading the Institute in 1965-69. In 1952-56 he was a delegate of Sejm of the Polish People's Republic. His scientific interests included: photoluminescence of solutions, cosmic rays, electron diffraction, ferromagnetism, quantum and atomic physics. He authored about fifty scientific publications. Prof. Szczeniowski was a member of the Polish Academy of Sciences since 1964.

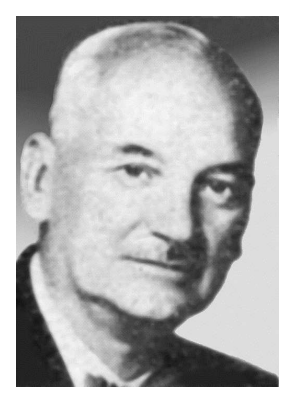

Wojciech, in non-Polish publications Adalbert, RUBINOWICZ (*22.II.1889 in Sadagóra or Sadhora near Chernivtsi - †13.X.1974 in Warsaw). He graduated from the University of Chernivtsi in 1912 and worked there as an assistant at the Department for Experimental Physics in 1912-16 defending his doctoral thesis entitled Zur Frage der strengen Lösungen einiger Beugungsprobleme am Keil und Winkelspiege in 1914. In 1916 he moved to München working in 1917 as an assistant of Arnold Sommerfeld. In 1916 W. Rubinowicz habilitated at the University of Chernivtsi. In 1919 he worked in Vienna, in 1919-20 in Copenhagen with Niels Bohr. In 1920-22 he became a professor of theoretical physics at the University of Ljubljana. In 1922-37 Wojciech Rubinowicz was a professor of theoretical physics at Lviv Polytechnic, serving as Dean of the General Faculty in 1925/26 and heading the Department for General Mechanics of the Engineering Faculty in 1935-37. Since July, 1937 till June, 1941, and in 1944-45 he was a professor at the Department for Theoretical Physics of the University of Lviv. In 1941-44 he participated in secret or "underground" teaching (Polish: tajne komplety $)^{1}$. In 1946-60 Prof. Rubinowicz headed

\footnotetext{
${ }^{1}$ This term here refers to the educational system under the German occupation during World War II, when official higher schools were dissolved and a network of secret Polish universities and other institutions was created [16]. Note also the Secret Ukrainian University in Lviv, which functioned in 1921-25 as a reaction against polonization attempts at the University of Lviv [17].
} 
the Department for Theoretical Mechanics of the Warsaw University, in 1950-53 was also a professor at the Institute of Mathematics in Warsaw. In 1953-60 he also worked at the Institute of Physics of the Polish Academy of Sciences. His scientific interests included: theory of diffraction, quantum theory of radiation, and mathematical physics. Prof. Rubinowicz elaborated the theory of electric radiation, formulated the rule of selection and polarization of electric dipole (1918) and quadrupole (192830) radiation, as well as solved the problem of "forbidden" spectral lines. He authored over 100 publications. Prof. Rubinowicz was a member of the Polish Academy of Arts and Sciences (correspondent since 1931 and full member since 1947), Polish Academy of Sciences (1952), he served as President of the Polish Physical Society in $1961-74$. [18]:

Additionally, six persons were affiliated as assistants

Edwin Karl Góra, worked as a junior assistant (Polish: asystent młodszy) in the academic year of 1937/38 [19];

Leopold Infeld, the only one to lecture separate courses on the position of a senior assistant (Polish: asystent starszy) in 1930-37 [20-22];

Zofja Krzysik / Orlicz after marriage in 1928, worked as a junior assistant (Polish: asystentka młodsza) in 1921-25 and did not publish any work during that period $[23,24]$;

Jadwiga Klonowiecka-Halaunbrenner, worked as a junior assistant in 1927-29 and did not publish any work during that period $[25,26]$;

Juda Kreisler, worked as a junior assistant in 1933-37 with a short break in 1936 [27];

Bazyli Milianczuk, worked first as a junior assistant (1933-35), then as a senior assistant in 1937$39[28,29]$.

Zenon Chrapływyj was not officially affiliated before $1940[30]$ but he actively participated in scientific discussions of the Department and in most of his scientific works from this period the affiliation at the Department is given.

Short biographical sketches of the abovementioned persons are given below.

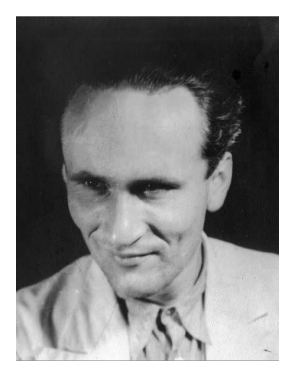

Edwin Karl GÓRA (*22.X.1911, Bielitz (Bielsko) - 28.II.1994, Providence, Rhode Island, USA). He graduated from the Jagiellonian University in 1934. In 1935-37 Edwin Góra was a teacher at St. Xavier's College (Bombay, India). In 1937/38 he was a junior assistant of the Department for Theoretical Physics at the University of Lviv, then in 1938/39 worked at the Institute for Theoretical Physics at the University of Warsaw. In 1939-44 Edwin Góra continued his education at the University of Leipzig, where in 1942 he obtained a degree of
Doctor of Natural Sciences for the thesis Quantentheorie der Strahlungsdämpfung supervised by Werner Heisenberg and Friedrich Hund. In 1944-46 Dr. Góra worked at the Institute for Theoretical Physics of the University of Munich, then he moved to the USA, first worked at the Steubenville Gollege (Ohio) in 1946-49 and since 1946 at the Providence College (Rhode Island). He authored several dozen publications.

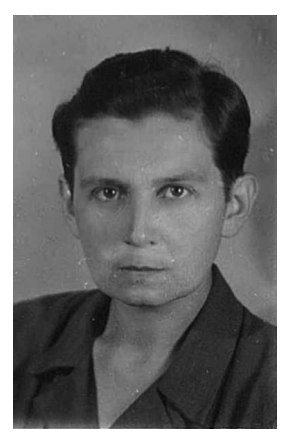

Jadwiga HALAUNBRENNER (KLONOWIECKA) $\left({ }^{*} 10\right.$. VI.1904, Krasnystaw, Poland - †1989). She graduated from the University of Lviv in 1927. In 1923-25 she worked as a demonstrator, in $1925-27$ as a junior assistant of the Department for Experimental Physics, since October 1927 till September 1929 as a junior assistant at the Department for Theoretical Physics of the University of Lviv. In 1928-41 and 1944-45 Jadwiga Halaunbrenner was a teacher in Lviv. In 1941-44 she participated in "underground" teaching. In 1945-74 Jadwiga Halaunbrenner worked at the University of Technology in Kraków (which was a part of the AGH University of Science and Technology before 1954). She obtained the doctoral degree in 1951 for the thesis O promieniowaniu soli potasowych [On the radiation of potassium salts]. Her scientific interests included: elastic properties of solids, physics of polymers, teaching physics. She authored several dozens of publications.

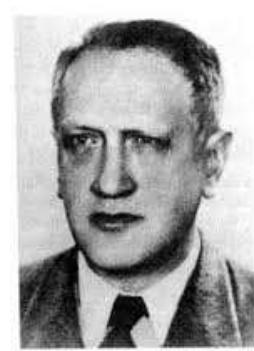

Leopold INFELD $\left({ }^{*} 20\right.$. VIII.1898 in Kraków - †15.I.1968 in Warsaw). He graduated from the Jagiellonian University. In 1921 Leopold Infeld obtained a doctoral degree based on the thesis Fale świetlne $w$ teorji wzgleddności [Light waves in the theory of relativity]. He was a teacher in private Jewish schools of Bendzyn and Konin in 1921-24 and Warsaw in 1924-29. Since November 1929 till June, 1937 he was a senior assistant at the Department for Theoretical Physics of the University of Lviv. Leopold Infeld obtained habilitation in 1931 for the work $O t$. zw. relacjach niedoktadności $w$ mechanice kwantowej $i$ o ich zwiazku z zagadnieniem pomiarów i przyczynowości /On the so-called uncertainty relations in quantum mechanics and their relation to the issue of measurement and causality]. He had several research leaves as a Fellow of the Rockefeller Foundation, working in 1933-34 with Max Born in Cambridge and in 1936-38 with Albert Einstein in Princeton. In 1938-50 Leopold Infeld worked as a professor at the University of Toronto. In 1950-68 he was a professor at the University of Warsaw. Leopold Infeld is a co-author of the nonlinear Born-Infeld electrodynamics and the theory of equations of motion in the general relativity of Einstein-InfeldHoffmann. He authored over 100 publications. Prof. Infeld was a member of the Polish Academy of Sciences (1952) and a member of several other scientific societies. 
Juda KREISLER $\left({ }^{*} 12 . X .1904\right.$ in Tłumacz or Tlumach, now Ivano-Frankivsk region, Ukraine - †1940s?). He graduated from the University of Lviv in 1927. In 1928-29 he was a teacher at a private Jewish gymnasium in Stanislav (now Ivano-Frankivsk), in 1929-31 taught in the 2nd State Gymnasium in Lviv, then in 1932-33 at a private Jewish gymnasium in Dubno. His doctoral degree was obtained from the University of Lviv in 1932 for the work $O$ rozmieszczeniu kierunkowem fotoelektronów $z$ warstwy $M$ [On the directional distribution of photoelectrons from the $M$ layer. In 1933-37 Juda Kreisler was a junior assistant-volunteer, then shortly worked at the Joint-stock company for the exploration and exploitation of bituminous materials ("Pionier", Spółka akcyjna dla poszukiwania i wydobywania materiałów bitumicznych we Lwowie). In 1940-41 he was a docent at the Department for Theoretical Physics at the University of Lviv; in 1937-39 he worked as a teacher in a school in Lviv. Dr. Kreisler authored five scientific papers. His fate is unknown, most probably he perished during World War II.

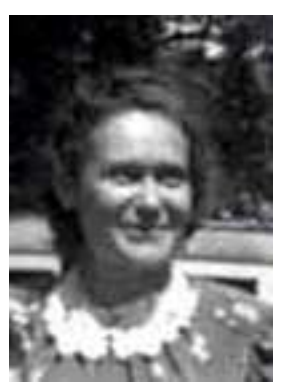

Zofja KRZYSIK (ORLICZ) $(* 26 . I X .1898$ in Foča, Bosnia $\nmid$ 05.XI.1999 in Poznań). She graduated from the University of Lviv in 1925. Since May 1922 till September 1926 she worked as a junior assistant at the Department for Theoretical Physics and in 1926-29 as a junior assistant at the Department for Experimental Physics of the University of Lviv. Zofja Orlicz was a teacher in a gymnasium in Lviv until 1941. In 1941-44 she participated in "underground" teaching, was a liaison and later chief of the conspiracy connection of the Lviv District of the Home Army (Polish: Armia Krajowa). In 1944-45 she was an assistant at the Lviv Medical Institute. In 1948-53 Zofja Orlicz was imprisoned in Wroclaw and Fordon (near Bydgoszcz) by the communist government for her participation in Armia Krajowa. She was rehabilitated in 1962. Zofja Orlicz was awarded the Medal of the Decade of the Restoration of Independence (1929), Order Virtuti Militari of the 5th degree (1965), the Cross of Valor (three times), the Cross of the Home Army, Officer's Cross of the Order of Poland Rebirth (1999).

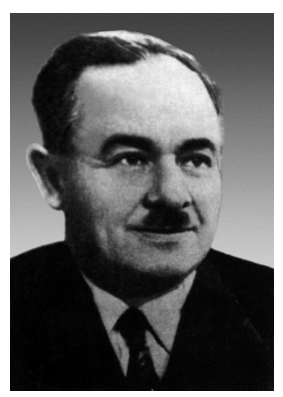

Wasyl or Bazyli MILIANCZUK (Ukrainian: Василь МІЛІЯНЧУК) $(* 10$. I.1905 in Dobrovidka, now Ivano-Frankivsk region, Ukraine †03.XI.1958 in Lviv). He studied at the University of Lviv in 1926-27 and then at the Lviv Polytechnic in 1927-33. His first scientific publications appeared yet in 1932: Milianczuk B. Zeemaneffekt der Quadrupollinien nach der Diracschen Theorie // Zeitschrift für Physik. - 1932. - B. 74, No. 11-12. - S. 810-824; Verwandlungseffekt der Quadrupollinien // ibid. - S. 825-847. Since October, 1933 till August, 1935 Wasyl Milianczuk was a junior assistant-volunteer at the Department for Theoretical Physics at the University of Lviv. He was on scientific training at the Institute of Physics of the Warsaw in 1935, at the Institute of Physics of the Leipzig University in 1936, where Heisenberg, Hund, and Debye worked at that time. In 1937 Wasyl Milianczuk worked at the Vilnius University. He obtained his doctorate in 1935 for the thesis "Wymuszone" prazki dipolowe [ "Forced" dipole lines], re-confirmed in 1946 as a Candidate of Sciences degree. Since October, 1937 till September, 1939 he was a senior assistant at the Department for Theoretical Physics of the University of Lviv. In 194041 Wasyl Milianczuk worked as an acting professor at the Department of Theoretical Mechanics, in 1944 he became a docent and in 1953 a professor of the Department for Theoretical Physics of the University of Lviv. He headed the Department since 1945. In 1957 Wasyl Milianczuk obtained the Doctor of Sciences degree for the work Влияние неоднородного межмолекулярного поля на атомные спектры [The influence of non-uniform molecular field on atomic spectra]. His scientific interests included: calculation of intensities and polarizations of quadrupole doublets split by magnetic field, longitudinal and transverse Zeeman effect, Compton scattering, the influence of non-uniform electric field in the plasma of gas discharge on spectral lines, issues of electrodynamics with higher derivatives, the theory of collisions of mesons with nucleons, theory of slow molecular collisions, etc. Prof. Milianczuk was one of the founders of the Lviv School of spectroscopy. He authored about thirty scientific publications. He was elected a member of the Shevchenko Scientific Society in 1932.

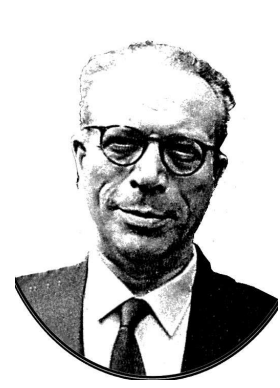

Zenon or Zenobjusz CHRAPŁYWYJ, Zeno CHRAPLYVY (Ukrainian: Зенон ХРАПЛИВИЙ) (*15.III.1904 in Lysivtsi near Zalishchyky, now Ternopil region, Ukraine - †01.X.1983 in St. Louis, USA). He studied at the University of Vienna in 1923-25, at the Jagiellonian University in 1925-26, and at the University of Lviv in 1926-29. In 1929-30 Z. Chrapływyj was an acting assistant at the Department of Mathematics at the University of Lviv. In 1932 obtained a doctoral degree for the thesis O pewnych trudnościach $w$ mechanice falowej /On some difficulties in the wave mechanics/, which was prepared at the Department for Theoretical Physics of the University of Lviv. In 1936-39 he was a teacher at the Lviv Academic Gymnasium. In 1939-41 Z. Chraplyvy worked at the University of Lviv as a vice-rector and a professor at the Department for Theoretical Physics. In 1941-48 he worked at the Ukrainian Free University (in Prague, then in München after World War II) and in 194872 was a professor at the St Louis University (USA). The main field of his scientific interests was relativistic quantum mechanics. He was elected a member of the Shevchenko Scientific Society in 1934. Prof. Chrapływyj was a member of the New York Academy of Sciences and the American Physical Society member. 
Four more names appeared in some publications from the 1930s with the affiliation listed as 'Zakład Fizyki Teoretycznej U. J. K.' or abbreviated as 'Z. F. T. U. J. K.' with 'U. J.K.' standing for the university name 'Uniwersytet Jana Kazimierza', namely: Abraham Melamid (in 1937, upon naturalization as a Palestinian citizen, he changed his name to Abraham Amery, אברהם אמרי [31]), Bolesław Matuła, Irena Postępska, and M. Tymoszyk (Михайло Тимошик). These persons were the students at that period [32] and, evidently, specialized in theoretical physics.

Note that these were not the first students' papers at the Department: yet in 1909, Volodymyr Kučer (Kuczer; Володимир Кучер) published an article:

Кучер B. Основи елєктронїки // Збірник математично-природописно-лїкарської секциї Наукового Товариства імени Шевченка. - 1909. - Т. XIII. - C. $1-68$.

\section{BIBLIOGRAPHY AND COMMENTS}

The following list is, to my knowledge, the most complete information about publications of the Department for Theoretical Physics of the University of Lviv for the respective period. It concludes two previous studies $[5,6]$ finalizing the pre-1939 time.

The list contains all kinds of publications where the representatives of the Department are listed as authors, editors, translators, etc. In some publications the affiliation is not given, so the attribution was made based on biographical details.

Within each year, publications are ordered according to their type. First, books or chapters are listed, then research papers are given followed by popular articles, and finally other publication types are placed: reviews, abstracts, obituaries, etc.

Items preceded by an asterisk $\left(^{*}\right)$ were not checked de visu, the respective information was cross-checked in several library catalogs, including the libraries of the University of Lviv, University of Warsaw, Jagiellonian University, Yale University, National Library of China, National Diet Library (Japan), British Library, Library of Congress, as well as the WorldCat database [33].

Some title pages and book covers are shown in Figs. 1-3.

1914

1. Odczyt prof. dra K. Zakrzewskiego... p.t.: "O pewnych zagadnieniach fizyki współczesnej" // Kosmos: czasopismo polskiego Towarzystwa przyrodników imienia Kopernika. - 1914. - Rocznik XXXIX, Zeszyt 1-3. - S. 290-291.

\section{5}

2. Zakrzewski K. O nowych wynikach analizy widmowej // Kosmos: czasopismo polskiego Towarzystwa przyrodników imienia Kopernika. 1915. - Rocznik XL, Zeszyt 1-6. - S. 196-197.
3. Witkowski A., Zakrzewski K. Zarys Fizyki. Lwów: Nakładem Zakładu Narodowego im. Ossolińskich, 1916. - $474 \mathrm{~s}$.

4. Zakrzewski C. Bemerkung zu der Abhandlung des Hrn. George Jaffé u. d. T. "Zur Theorie der Lichtabsorption in Metallen und Nichtleitern" // Annalen der Physik. Fierte Folge. - 1916. - B. 49 (Der ganzen Reihe 354. Band), Nr. 4. - S. 456.

5. Zakrzewski $K$. Über die spezifische Wärme der Flüssigkeiten bei konstantem Volumen // Bulletin International de l'Académie des Sciences de Cracovie. Classe des sciences mathématiques et naturelles. Série A: Sciences mathématiques. 1916. - S. 33-49.

6. Zakrzewski K. Über die spezifische Wärme der Flüssigkeiten bei konstantem Volumen. II // Bulletin International de l'Académie des Sciences de Cracovie. Classe des sciences mathématiques et naturelles. Série A: Sciences mathématiques. 1917. - S. 86-101.

7. Przemówienie p. K. Zakrzewskiego p. t.: O działalności naukowej ś. p. Maryana Smoluchowskiego // Kosmos: czasopismo polskiego Towarzystwa przyrodników imienia Kopernika. 1917. - Rocznik XLII, Zeszyt 5-12. - S. 233-252.

1921

8. Loria S. Względność i grawitacya: teorya A. Einsteina. - Lwów: Nakł. H. Altenberga, 1921. - [6], $93 \mathrm{~s}$.

9. Loria $S$. Eter i materja: Wykład wygłoszony podczas inauguracji roku akademickiego 1920/21 w Uniwersytecie Jana Kazimierza we Lwowie dnia 1. marca 1921. - we Lwowie: Nakładem H. Altenberga, 1921. - $15 \mathrm{~s}$.

10. Loria S. Względność i grawitacja. Teorja A. Einsteina: Wydanie drugie w nowem opracowaniu znacznie rozszerzone. - we Lwowie: Księgarnia Nakładowa H. Altenberga, 1922. - VIII, $159 \mathrm{~s}$.

11. Loria $S$. Kwantowa teorja seryj widmowych, cz. I. i II. // Roczniki Chemji: Organ Polskiego Towarzystwa Chemicznego - 1922. - T. II. S. $44-47$. 

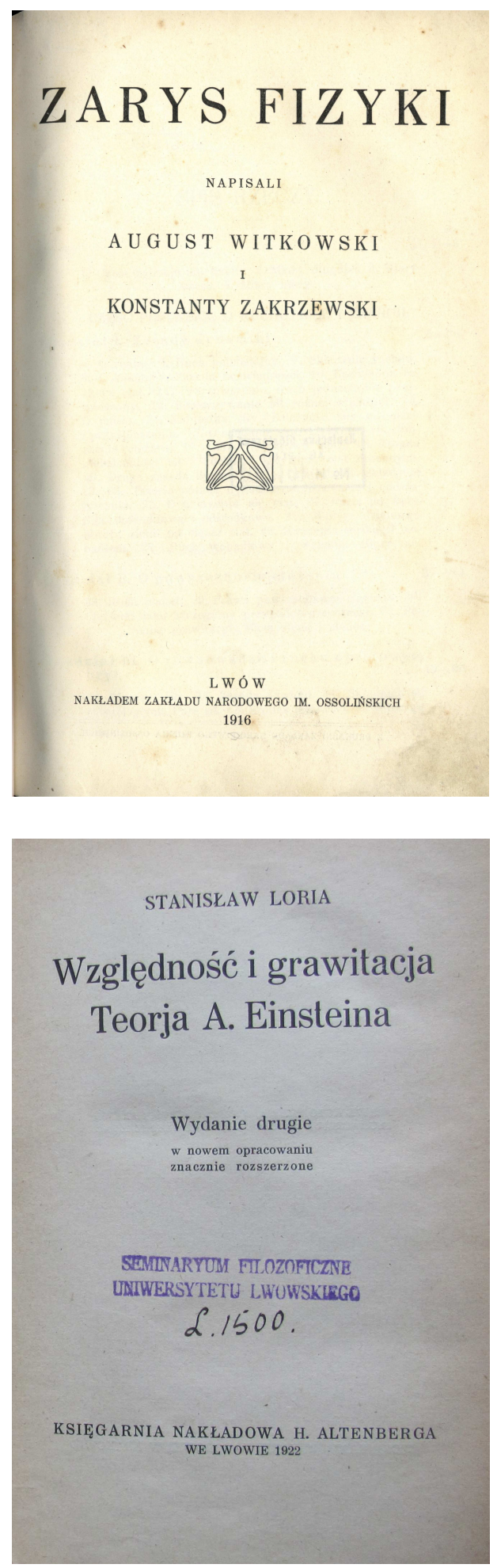

Fig. 1. Title pages of Zarys fizyki by August Witkowski and Konstanty Zakrzewski (1916) and Względność i grawitacja, 2nd edition, by Stanisław Loria (1922).

12. Loria $S$. Indirectly excited fluorescence spectra // Phys. Rev. - 1925. - Vol. 26, No. 5. P. 573-584.
Professor Loria worked at the Norman Bridge Laboratory of Physics, California Institute of Technology, in 1923-25. While in the above paper his relation to the University of Lviv is mentioned in the footnote as "Professor of Physics at the University, Lwow, Poland", another paper from that period contains no such reference:

- Loria $S$. The metastable $2 p_{3}$-state of mercury atoms // Proceedings of the National Academy of Sciences of the United States of America. - 1925. - Vol. 11, No. 11. - P. 673679.

1926

13. Loria S. Zur Frage nach der Abhängigkeit der sensibilisierten Fluoreszenz vom Zusatz der Gase // Physikalische Zeitschrift. - 1926. B. 38 , No. $9-10 .-$ S. $672-674$.

In 1927-30, the position of the professor of theoretical physics at the University of Lviv was not filled. Prof. Loria was appointed a professor of experimental physics in the end of 1926 and remained an acting professor of theoretical physics. His papers from this period thus can be attributed to the bibliography of the Department with some precautions:

(a) Loria S. Alchemja średniowieczna w świetle fizyki dzisiejszej // Kosmos: czasopismo polskiego Towarzystwa przyrodników imienia Kopernika. Serja B. - 1929. Rocznik LIV, Zeszyt 1. - S. 104-118.

(b) Loria $S . \quad$ Znaczenie prac Marji Skłodowskiej-Curie dla rozwoju fizyki i chemji // Kosmos: czasopismo polskiego Towarzystwa przyrodników imienia Kopernika. Serja B. - 1930. - Rocznik LV, Zeszyt 1. - S. 1-9.

It might be also interesting to note the following publication by Zofja Krzysik:

- Krzysikówna $\quad Z$. $\quad$ O związku między promieniami $\beta$ i $\gamma$ (Referat na podstawie prac p. L. Meitner) // Kosmos: czasopismo polskiego Towarzystwa przyrodników imienia Kopernika. Serja B. - 1928. - Rocznik LIII, Zeszyt 1. - S. 10-23.

At the time of publication (and almost certainly writing) Zofja Krzysik was affiliated at the Department for Experimental Physics of the University of Lviv. The above item is the only her article I was able to locate.

14. Infeld L. Kausalgesetz und Quantenmechanik. II // Physikalische Zeitschrift. - 1930. - B. 61, No. 9-10. - S. 703-711. 
15. Infeld L. Eine Bemerkung zu der Arbeit von Herrn G. Wataghin: Über die Unbestimmtheitsrelationen der Quantentheorie // Physikalische Zeitschrift. - 1930. - B. 66, No. 910. - S. 708 .

16. Infeld L. O t. zw. relacjach niedokładności w mechanice kwantowej i o ich związku z zagadnieniem pomiarów i przyczynowości: [praca habilitacyjna]. - Lwów: Nakładem autora, 1930. - $23 \mathrm{~s}$.

1931

17. Infeld $L$. Über eine Interpretation der neuen Einsteinschen Weltgeometrie auf dem Boden der klassischen Mechanik // Phys. Zs. 1931. - B. 32. - S. 110-112.

18. Infeld L. Über die Struktur der Elektronwelle // Bulletin International de l'Académie Polonaise des Sciences et des Lettres. Classe des sciences mathématiques et naturelles. Série A: Sciences mathématiques. - 1931. - P. 201-231.

19. Szczeniowski S., Infeld $L$. The influence of a cloud of electrons on the structure of de Broglie waves // Bulletin International de l'Académie Polonaise des Sciences et des Lettres. Classe des sciences mathématiques et naturelles. Série A: Sciences mathématiques. - 1931. - P. 482-488.

20. Infeld $L$. O fali elektronowej // Kosmos: czasopismo polskiego Towarzystwa przyrodników imienia Kopernika. Serja B. - 1931. - Rocznik LVI, Zeszyt II., III. i VI. - S. 117-124.

21. Szczeniowski $S$. Dzisiejszy stan mechaniki kwantowej: (Na marginesie książek Diraca i Heisenberga) // Mathesis Polska. - 1931. - T. VI, Nr. 3-4. - S. 102-115.

22. Infeld L., Eastowiecki A. O fali elektronowej // Mathesis Polska. - 1931. - T. VI, Nr. 9-10. S. $186-202$.

\section{2}

23. * Szczeniowski S., Ziemiecki S. Promieniowanie i materja: Idee i fakty fizyki nowoczesnej. Warszawa: Kasa im. Mianowskiego, 1932. - VIII, 261, [2] s.

24. Infeld $L$. Die verallgemeinerte Spinorenrechnung und die Diracschen Gleichungen // Phys. Zs. - 1932. - B. 33. - S. 475-483.

25. Szczeniowski S. Eine Bemerkung zur Arbeit von P. Sauter: Zum Kleinschen Paradoxon // Physikalische Zeitschrift. - 1932. - B. 73, No 7-8. - S. 553-559.
26. Szczeniowski S. E., Infeld L. O wpływie chmury elektronowej na strukturę fali de Broglie'a // Acta Physica Polonica. - 1932. - T. I, Zeszyt 1-2. - S. 37-46.

27. Melamid A. Bemerkungen zur Quasiergodenhypothese // Acta Physica Polonica. - 1932. Vol. I, Fasc. 1-2. - S. 281-283.

28. Szczeniowski $S$. Zur Frage des Übergangs der Elektronen in das Gebiet der negativen Energiewerte // Acta Physica Polonica. - 1932. Vol. I, Fasc. 3. - S. 363-386.

29. Infeld L. Zur nichholonomen Geometrie (Przyczynek do geometrii nieholonomicznej) // Prace matematyczno-fizyczne. - 1932. T. XXXIX. - S. 1-9.

30. Infeld $L$. Remarques sur le problème de la théorie unitaire des champs // Rendiconti della Reale Accademia nazionale dei Lincei. Classe di scienze fisiche, matematiche e naturali. - 1932. Vol. 15. - P. 157-160.

31. Szczeniowski S. Optyka fal materii // Wszechświat: pismo przyrodnicze. - 1932. - N 1. - S. 1218.

In 1932, two doctoral theses were defended at the Department, namely:

(a) Chraptywyj Z. O pewnych trudnościach w mechanice falowej: Przyczynki do teorji działania własnego elektronu i teorji ujemnych stanów energji.

(b) Kreisler J. O rozmieszczeniu kierunkowem fotoelektronów $\mathrm{z}$ warstwy $M$.

The preparation of the two above theses at the Department is mentioned as merits of Szczepan Szczeniowski, who headed the Department at that time, in the request to the Ministry of Religious Affairs and Public Education (Polish: Ministerstwo Wyznań Religijnych i Oświecenia Publicznego) about his appointment for the position of an extraordinary professor of theoretical physics at the University of Lviv.

32. * Infeld L. Nowe drogi nauki. Kwanty i materja. - Warszawa: Nakł. "Mathesis Polskiej", 1933. - X, 284 s. + wklejka.

33. Infeld L., van der Waerden B. L. Die Wellengleichung des Elektrons in der allgemeinen Relativitätstheorie // Sitzungsberichte der Preussischen Akademie der Wissenschaften. Physikalisch-mathematische Klasse. - 1933. Nr. IX. - S. 380-401. 
34. Szczeniowski $S$. Zur Frage des Überganges der Elektronen in das Gebiet der negativen Energiewerte // Bulletin International de l'Académie Polonaise des Sciences et des Lettres. Classe des sciences mathématiques et naturelles. Série A: Sciences mathématiques. - 1933. - P. 2139.

35. Kreisler J. Über die Verteilung der Photoelektronen der $M$-Schale wasserstoffähnlicher Atome // Acta Physica Polonica. - 1933. - Vol. II, № 1. - S. 7-22.

36. Chraptywyj Z. W. O ujemnych poziomach energji w teorji Diraca // Acta Physica Polonica. - 1933. - T. II, Zeszyt 2. - S. 193-204.

37. Chraptywyj Z. O potencjale własnym elektronu w mechanice falowej// Acta Physica Polonica. - 1933. - T. II, Zeszyt 2. - S. 205-213.

38. Chraptywyj $Z$. Uwagi do pracy p.t. "O potencjale własnym elektronu w mechanice falowej" // Acta Physica Polonica. - 1933. - T. II, Zeszyt 4. - S. 417-418.

39. Szczeniowski S. Nowe cząsteczki: Odkrycie dodatniego elektronu // Mathesis Polska. 1933. - T. 8, Nr. 3-4. - S. 43-52.

40. Szczeniowski S. [Recenzja:] Infeld Leopold dr., doc. Uniw. J. K. Nowe Drogi Nauki. Kwanty i materja. Str. X, 284 z 27 fig. w tekście i na 3 tabl. Nakładem "Mathesis Polskiej". Warszawa. 1933 // Mathesis Polska. 1933. - T. 8, Nr. 5-6. - S. 90-91.

41. Szczeniowski $S$. Nowe dane o positronie // Mathesis Polska. - 1933. - T. 8, Nr. 7-8. - S. 106109.

Leopold Infeld was a Research fellow of the Rockefeller Foundation in 1933-34. He was given a paid leave of absence from the University of Lviv for the period of 01 December 1933 to 31 December 1934 to work in Cambridge with Max Born. Infeld's papers from that period do not bear any sign of affiliation at the University of Lviv. The following list of nine papers is thus given for completeness:

(a) Born M., Infeld L. Electromagnetic mass // Nature. - 1933. - Vol. 132, No. 3347. P. 970.

(b) Born M., Infeld L. Foundations of the new field theory // Nature. - 1933. Vol. 132, No. 3348. - P. 1004.

(c) Born M., Infeld L. Foundations of the new field theory // Proceedings of the Royal Society of London. Series A, Mathematical and Physical Sciences. - 1934. - Vol. 144, No. 852. - P. 425-451. (d) Born M., Infeld L. Remarks on the paper by Frenkel on Born's theory of the electron // Proceedings of the Royal Society of London. Series A, Mathematical and Physical Sciences. - 1934. - Vol. 146, No. 859. P. 935.

(e) Born M., Infeld L. On the quantization of the new field equations. I // Proceedings of the Royal Society of London. Series A, Mathematical and Physical Sciences. - 1934. — Vol. 147, No. 862. - P. 522-546.

(f) Born M., Infeld L. Principles de la nouvelle électrodynamique quantique // Comptes Rendus hebdomadaires des séances de l'Académie des Sciences. - 1934. - T. 199. - P. 1297-1298.

(g) Born M., Infeld L. Déduction de l'équation d'ondes Dirac á partir l'électrodynamique quantique // Comptes Rendus hebdomadaires des séances de l'Académie des Sciences. - 1934. - T. 199. - P. 1596-1598.

(h) Infeld L. Dirac's equation in the general relativity theory // Acta Physica Polonica. - 1934. - Vol. III. - P. 1-14.

(i) Born M., Infeld L. On the quantization of the new field equations. II // Proceedings of the Royal Society of London. Series A, Mathematical and Physical Sciences. - 1935. - Vol. 150, No. 869. - P. 141-166.

1934

42. Infeld $L$. The world in modern science. Matter and quanta / translated by Louis Infield; with an introduction by Albert Einstein. - New York: G. P. Putnam's Sons, 1934. - 287 p. (US edition); London: V. Gollancz, Ltd., 1934 (* British edition).

This is the English translation of item 32. It was used for subsequent translations into other languages: Dutch, Ukrainian, Chinese, and Japanese.

43. Szczeniowski S. Promienie kosmiczne // Od gwiazdy do atomu / J. Weyssenhoff, Cz. Białobrzeski, L. Wertenstein, Sz. Szczeniowski. Warszawa: Trzaska, Evert i Michalski S. A., [1934]. - S. 129-186.

44. Milianczuk B. Die Intensitäten der "erzwungenen" Dipollinien // Acta Physica Polonica. 1934. - Vol. III. - S. 123-131.

45. Milianczuk B. Über den Einfluss des magnetischen Feldes auf den Comptoneffekt // Acta Physica Polonica. - 1934. - Vol. III. S. 133-142.

46. Milianczuk B. Zur Frage nach den Summenregeln in "erzwungenen" Dipolmultipletts // Sammelschrift der mathematischnaturwissenschaftlich-ärtzlichen Sektion der Ševčenko-Gesellschaft der Wissenschaften in Lwiw (Lemberg). - 1934. - B. XXX. - S. 125-128. 
47. Kreisler J. Sztucznie wzbudzona promieniotwórczość // Mathesis Polska. - 1934. - T. 9, Nr. 5-6. - S. 82-87.

48. Szczeniowski S. Nowe oblicze fizyki // Kultura i wychowanie. - 1934. - Rok I. - S. 205-226.

\section{5}

49. Haas A. Zasady fizyki. Światło, elektryczność, ciepło, materja / Przełożył dr. Sz. Szczeniowski. - Warszawa: Trazaska, Evert i Michalski S. A., [1935]. - VI, 309 s.

50. * Infeld L. Stof, straling en atomen: het wereldbeeld in de moderne natuurwetenschappen / met een voorwoord van Albert Einstein; nederlandse vertaling van M. C. Geerling. - Amsterdam: N.V.D.B. Centen's Uitgevers-Mij., 1935. - VIII, 288 S.

This is the Dutch translation of item 42 .

51. * 科學在今日 / 茵菲爾原著; 秦仲實譯。一上海: 開明書店, 民國24[1935]. 一 207頁.

Kē xué zài jīn rì / Y̌n fēi ěr (L. Infeld); translated by Qín Zhòng Shí. - Shànghăi: Kāi míng shū diàn, 1935. - 207 p.

This is one of the Chinese translations of item 42. The year of publication is given in the Republic of China (Minguo) calendar. The description is based on the WorldCat data and [34]. Note that in the latter Beijing is mentioned as the place of publication.

52. Milianczuk B. Über die Summenregeln in normalen "erzwungenen" Dipolmultipletts // Acta Physica Polonica. - 1935. - Vol. IV, Fasc. 1/2. - S. 65-71.

Three more papers by Bazyli Milianczuk appeared in 1935, with affiliation listed as "Technische Hochschule in Lemberg". Addidionally, in 1935 he also defended a doctoral thesis. The following list is given for completeness:

(a) Milianczuk B. Über die magnetische Dipolstrahlung // Bulletin International de l'Académie Polonaise des Sciences et des Lettres. Classe des sciences mathématiques et naturelles. Série A: Sciences mathématiques. 1935. - S. 430-437.

(b) Milianczuk B. Über die Dispersion des Lichtes in der Umgebung der magnetischen Dipollinien // Bulletin International de l'Académie Polonaise des Sciences et des Lettres. Classe des sciences mathématiques et naturelles. Série A: Sciences mathématiques. - 1935. - S. 438-444.

(c) Milianczuk B. Zur Frage nach der Strahlung eines magnetischen Dipols // Sitzungsberichte der mathematischnaturwissenschaftlich-ärztlichen Sektion der Ukrainischen Ševčenko-Gesellschaft der Wissenschaften in Lemberg (Lwiw). - 1935. Heft XVII. - S. 6-7. (d) Milianczuk B. "Wymuszone" prążki dipolowe: Praca doktorska (1935).

53. Kreisler J. Die Übergangswahrscheinlichkeiten im zweifach angeregten Heliumatom // Acta Physica Polonica. - 1935. - Vol. IV, Fasc. 1/2. S. 151-161.

Note. Curiously, this paper is cited several times with an author given as "K. Kreisler", cf. [35]. This is due to a typo in even-page headers in the original publication, where "K. Kreisler" is printed instead of "J. Kreisler".

54. Postęska I. Harmonischer Oszillator nach der Diracschen Wellengleichung // Acta Physica Polonica. - 1935. - Vol. IV, Fasc. 3. - S. 269280.

55. Chraptywyj $Z$. On the Lorentz equation of motion in the new electrodynamics // Acta Physica Polonica. - 1935. - Vol. IV, Fasc. 4. - P. 395404 .

56. Matuła B. Rekursionsformeln der verallgemeinerten Kugelfunktionen // Acta Physica Polonica. - 1935. - Vol. IV, Fasc. 4. - S. 419426.

57. Infeld L. Problem struktury elektronu w fizyce współczesnej // Mathesis Polska. - 1935. - T. 10, Nr. 1-2. - S. 27-39.

58. Szczeniowski S. [Recenzja:] Hermann Weyl. Mind and Nature. Philadelphia 1934. University of Pennsylvania Press. S. VI +100 // Nauka Polska. Jej potrzeby, organizacja i rozwój. - 1935. - T. XX. - S. 317-322.

1936

59. Szczeniowski S. Promienie kosmiczne Od gwiazdy do atomu / J. Weyssenhoff, Cz. Białobrzeski, L. Wertenstein, Sz. Szczeniowski. - Wyd. 2 uzup. - Warszawa: Trzaska, Evert i Michalski S. A., 1936. - S. 161-238.

60. * 物質與量子 / 茵菲爾原著; 何育杰譯. 一 上海: 商務印書館, 1936 .

Wù zhí yǔ liàng ž́ / Yīn feei ěr (L. Infeld); translated by Hé Yù Jié. - Shànghăi: Shāng wù yìn shu guăn, 1936.

This is another Chinese translations of item 42. According to the Chinese National Library catalog this item was printed in two parts, pages up to 133 and 135-260; in the WorldCat database the number of pages is 233 .

61. Infeld $L$. The new electrodynamics and the fine structure constant // Nature. - 1936. Vol. 137, No. 3468. - P. 658.

62. Infeld $L$. The new action function and the unitary field theory // Proc. Camb. Philos. Soc. Math. Phys. Sci. - Vol. 32, Iss. 1. - P. 127-137. 
63. Chraplywy Z. Sur les équations de mouvement de l'électrodynamique nouvelle // Comptes Rendus hebdomadaires des séances de l'Académie des Sciences. - 1936. - T. 202. P. 396-397.

64. Infeld $L$. Nowe funkcje działania w jednolitej teorji pola // Program VIII Zjazdu fizyków polskich, Lwów, 28.IX - 2.X 1936. — Lwów : Nakładem Komitetu organizacyjnego, 1936. - S. 35.

65. Infeld L. Stała 137, pole protonu, a jednolita teorja pola // Program VIII Zjazdu fizyków polskich, Lwów, 28.IX - 2.X 1936. — Lwów : Nakładem Komitetu organizacyjnego, 1936. - S. 35.

66. Chraptywy $Z$. Równanie ruchu Lorentza w nowej elektrodynamice // Program VIII Zjazdu fizyków polskich, Lwów, 28.IX - 2.X 1936. — Lwów : Nakładem Komitetu organizacyjnego, 1936. S. 35 .

67. Chraptywy Z. Atom wodoru a jednolita teorja pola // Program VIII Zjazdu fizyków polskich, Lwów, 28.IX - 2.X 1936. - Lwów : Nakładem Komitetu organizacyjnego, 1936. - S. 35-36.

68. Postepska I. Oscylator harmoniczny według równania Diraca // Program VIII Zjazdu fizyków polskich, Lwów, 28.IX - 2.X 1936. - Lwów : Nakładem Komitetu organizacyjnego, 1936. S. 36 .

69. Matuta B. Elektron w polu dodatnio naładowanego jądra, zawierającego pojedynczy biegun magnetyczny // Program VIII Zjazdu fizyków polskich, Lwów, 28.IX - 2.X 1936. - Lwów : Nakładem Komitetu organizacyjnego, 1936. - S. 36-37.

70. Tymoszyk M. Absorpcja trzech fotonów metodą Diraca // Program VIII Zjazdu fizyków polskich, Lwów, 28.IX - 2.X 1936. - Lwów : Nakładem Komitetu organizacyjnego, 1936. S. 37.

71. Krejsler J. Uwagi o Schrödingerowskiej postaci jednolitej teorji pola Borna-Infelda // Program VIII Zjazdu fizyków polskich, Lwów, 28.IX - 2.X 1936. - Lwów : Nakładem Komitetu organizacyjnego, 1936. - S. 37.

72. Krejsler J. Przyczynek do teorji rozbijania deutonów przez deutony // Program VIII Zjazdu fizyków polskich, Lwów, 28.IX - 2.X 1936. - Lwów : Nakładem Komitetu organizacyjnego, 1936. - S. 37-38.
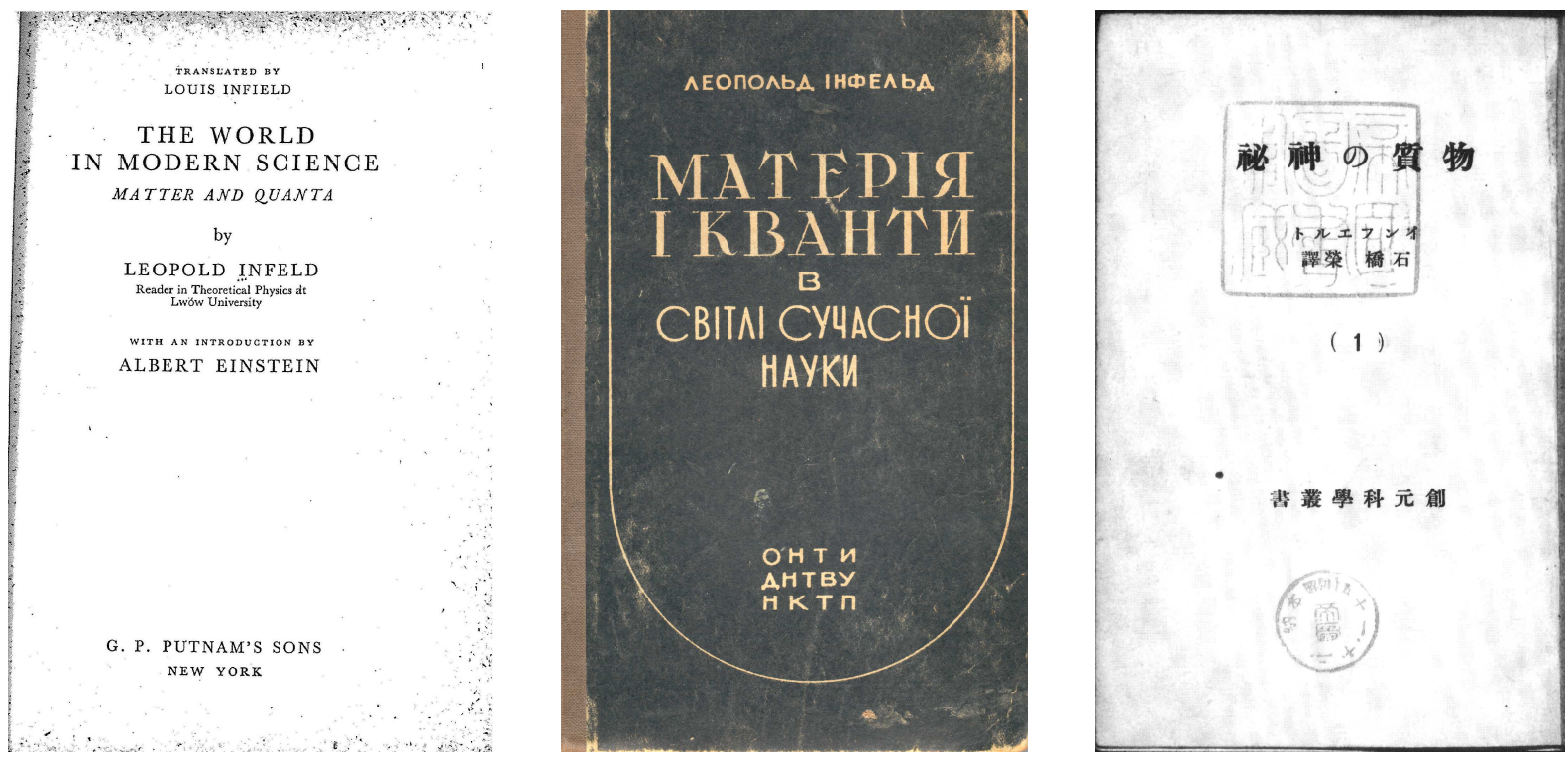

Fig. 2. Title pages of the English, Ukrainian, and Japanese translations of Nowe drogi nauki by Leopold Infeld (1933).

1937

73. Jeans J. Horyzonty nowej nauki / Z drugiego wydania oryginału przełożył i przedmową zaopatrzył dr. Sz. Szczeniowski. - Warszawa: Nakładem "Mathesis Polskiej", 1937. - [8], 281 s.
74. Інфельд Л. Матерія і кванти в світлі сучасної науки / Переклад з англійського видання 1934 року під редакцією проф. А. В. Желеховського. - Харків: Державне науково-технічне видавництво України, 1937. - 208 с.

This is the Ukrainian translation of item 42 . 
75. Infeld $L$. A new group of action functions in the unitary field theory. II // Proceedings of the Cambridge Philosophical Society. Mathematical and Physical Sciences. - Vol. 33, Iss. 1. - P. 7078 .

76. Infeld $L$. The Lorentz transformations in the new quantum electrodynamics // Proceedings of the Royal Society of London. Series A, Mathematical and Physical Sciences. - 1937. - Vol. 158, No. 894. - P. 368-371.

77. Chraptywy $Z$. O pojęciu potencjału w nowej elektrodynamice. - Zum Potentialbegriff in der neuen Elektrodynamik // Bulletin International de l'Académie Polonaise des Sciences et des Lettres. Classe des sciences mathématiques et naturelles. Série A: Sciences mathématiques. - 1937. - S. 509-520.

78. Chraptywyj Z. On the Lorentz' equation of motion in the new electrodynamics II // Acta Physica Polonica. - 1937. - Vol. VI, Fasc. 1. P. 31-39.

79. Kreisler J. Zur Theorie der Zertrümmerung von Deuteronen durch Deuteronen // Acta Physica Polonica. - 1937. - Vol. VI, Fasc. 4. S. 327-334.

80. Chraplywy $Z$. The fundamental notions of electrodynamics and the unitary field theory // Sitzungsberichte der mathematischnaturwissenschaftlich-ärztlichen Sektion der Ukrainischen Ševčenko-Gesellschaft der Wissenschaften in Lemberg (Lwiw). - 1937. - Heft XXV. - P. 1112 .

81. Храпливий 3. Основні поняття елєктродинаміки а унітарна теорія поля // Збірник математично-природописно-лікарської секції Наукового Товариства імени Шевченка. 1937. - T. XXXI. - C. 51-56.

Two other items by Zenon Chraplywyj were published in 1937-38, but these do belong to his dydactic work and thus are linked to his official affiliation as a teacher at Lviv Academic Gymnasium, so they are placed beyond the main list here:

(a) Chraplywy Z. O wprowadzeniu wielkosci i jednostek elektrycznych // Fizyka i chemja w szkole. - 1937.

(b) Храпливий 3. Нарис фізики: підручник для IV кляси riмназіі. - Państwowe Wydawnictwo Książek Szkolnych we Lwowie, 1938. - 282, [6] с., [1] л. вклейка.

82. Szczeniowski S. Wpływ fizyki na rozwój kultury dzisiejszej // Nauka Polska. Jej potrzeby, organizacja i rozwój. - 1937. - T. XXII. - S. 2536 .

Note. While S. Szczeniowski was affiliated as a professor at the University of Vilnius since January, 1937, the above item belongs most likely yet to the time he worked in Lviv. Such a conclusion can be drawn from the sections on chronicles from scientific meetings in the journal Nauka Polska: the issue from 1937 contains information from events of 1936 (and this holds for other years), thus it was in the course of preparation in 1936.
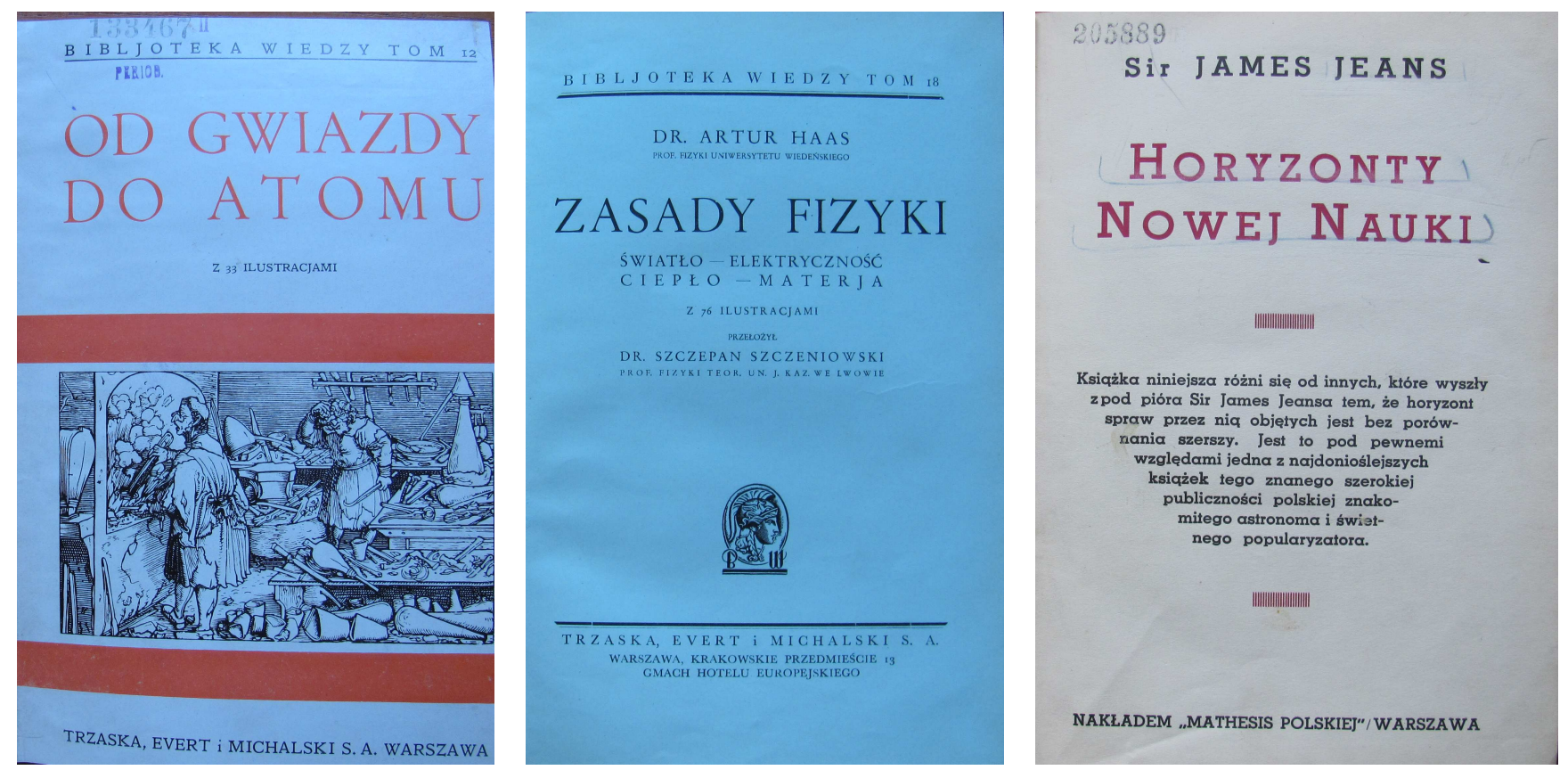

Fig. 3. Title pages of books co-authored or translated by Szczepan Szczeniowski. 


\section{A. ROVENCHAK}

1938

83. Rubinowicz A. Does iron occur in the solar corona? // Nature. - 1938. - Vol. 141, No. 3558. - P. 81.

84. Rubinowicz $A$. On the anomalous propagation of phase in the focus // Phys. Rev. - 1938. Vol. 54, Iss. 11. - P. 931-936.

85. Góra E. Zur theorie des Comptoneffekts// Acta Physica Polonica. - 1938. - Vol. VII, Fasc. 2. - S. 159-176.

86. Rubinowicz W. "Skok" fazy w ognisku fali kulistej // Sprawozdania Towarzystwa Naukowego we Lwowie. - 1938. - Rocznik XVIII. - S. 345346.

87. Rubinowicz $W$. Dirakowskie zagadnienie jednoelektronowe $\mathrm{w}$ reprezentacji pędowej // Sprawozdania Towarzystwa Naukowego we Lwowie. - 1938. - Rocznik XVIII. - S. 346-347.

88. Milianczuk B. Prążki "wzbronione" // Mathesis Polska. - 1938. - T. 11, Nr. 3-4. - S. 33-49.

89. Góra E. W sprawie teorii efektu Comptona // Program IX Zjazdu fizyków polskich w Wilnie, 28.IX - 1.X 1938. - Wilno : Nakładem Komitetu organizacyjnego, 1938. - S. 50-51.

90. Milianczuk B. Rozpraszanie neutronów na protonach // Program IX Zjazdu fizyków polskich w Wilnie, 28.IX - 1.X 1938. - Wilno : Nakładem Komitetu organizacyjnego, 1938. - S. 53-54.
1939

91. Szczeniowski $S$. Hipoteza istnienia neutrina i jej zastosowania // Prace matematycznofizyczne. - 1939. - T. 46. - S. 69-95.

Note. While S. Szczeniowski was affiliated as a professor at the University of Vilnius since January, 1937, the above item does belong to the time he worked in Lviv as the title bears the following footnote: "Odczyt wygłoszony na VIII Zjeździe Fizyków Polskich we Lwowie (wrzesień 1936 r.)", i. e., "Report presented at the VIII Congress of Polish Physicists in Lviv (September 1936)".

1940

92. 物質の神秘 / インフエルト著; 石橋栄訳. 一東京: 創元社, 1940. - 282頁.

Busshitsu no shinpi / Infueruto (L. Infeld); translated by Ishibashi Sakae. - Tōkyō: Sōgen-sha, 1940. $-282 \mathrm{p}$

This is the Japanese translation of item 42 .

\section{ACKNOWLEDGEMENTS}

I would like to express my gratitude for the help in compiling this bibliographic list to the following persons and institutions: Institute of Physics Library, Jagiellonian University (Kraków); Lviv University Scientific Library; Accademia dei Lincei; Dr. Yuriy Chorniy (Vilnius University); Masayuki Ito, Akiko Endo, and Mika Kiya (National Diet Library, Japan); Dr. Natalia Kotsyba (Warsaw University); Lilianna Lewandowska (Museum Politechniki Krakowskiej); Dr. Yaroslav Pavlyukh (Halle); Charles Riley (Yale University Library); Adam Rovenchak (Lviv Stefanyk Scientific Library). Advices and hints from Prof. Andrzej Kajetan Wróblewski were of invaluable help in complementing the list.
[1] L. Finkel, S. Starzyński, Historia uniwersytetu Lwowskiego: $w 2$ cz. (Lwów, 1894).

[2] M. Smoluchowski, in Pisma Mariana Smoluchowskiego, T. 3 (Polska Akademia Umiejętności, Kraków, 1928), s. 223.

[3] Österreichisches biographisches Lexikon. 1815-1950 (Österreichischen Akademie der Wissenschaften, Wien, 1957-2005). B. 1, Wien 1993, S. 279.

[4] Encyclopedia: Lvivs'kyj nacional'nyj universytet imeni Ivana Franka. T. 1 (LNU imeni Ivana Franka, Lviv, 2011).

[5] A. Rovenchak, Acta Phys. Polon. A 116109 (2009); Postępy Fizyki 60, 205 (2009).

[6] A. Rovenchak, Condens. Matter Phys. 1540002 (2012).

[7] T. Piech, Postępy fizyki T. 9, Zesz. 4 (1958), s. 371-378.

[8] A. Strzałkowski, in Ztota Ksiega Wydziatu Matematyki $i$ Fizyki Uniwersytetu Jagiellońskiego, pod red. B. Szafirskiego (Kraków, 2000). s. 467.

[9] L. Infeld, Acta Phys. Polon. 18, 3 (1959).

[10] A. Kiejna, Postępy Fizyki 54, 77 (2003).
[11] H. Cofta, Postępy Fizyki 31, 253 (1980).

[12] J. Dąbrowski, Acta Phys. Polon. A 46, 649 (1974).

[13] State Archive of Lviv Oblast. Repository 26, Desc. 5, Case 714

[14] State Archive of Lviv Oblast. Repository 26, Desc. 5, Cases 1123, 1124.

[15] State Archive of Lviv Oblast. Repository 26, Desc. 5, Case 2185.

[16] N. Davis, God's Playground A History of Poland. Vol. II: 1795 to the Present (Oxford University Press, 2005), p. 345 .

[17] N. L. Chirovsky, An introduction to Ukrainian history, vol. 3 (Philosophical Library, New York, 1986), p. 244.

[18] University curricula and staff were published regularly under titles Spis wyktadów i sklad uniwersytetu za rok akademicki... or similar. These titles were checked since academic year of 1917/18 till 1938/39.

[19] The Cowl (Providence College, Providence, R. I., Oct. 5, 1949), p. 3. An interwiew with E. Góra in an audio and video format is available at http://www.gora.us. 
[20] State Archive of Lviv Oblast. Repository 26, Desc. 5, Case 770.

[21] E. Infeld, Gen. Rel. Grav. 1, 191 (1970).

22] R. Gajewski, Acta Phys. Polon. B 30, 3003 (1999).

[23] State Archive of Lviv Oblast. Repository 26, Desc. 5, Case 1048.

[24] L. Maligranda, W. Wnuk, Roczniki Polsk. Tow. Mat. Ser. II: Wiadomości matematyczne 36, 85 (2000).

[25] State Archive of Lviv Oblast. Repository 26, Desc. 5, Case 355.

[26] Jadwiga Halaunbrenner (1904-1989), in Jednostki Międzywydziatowe Politechniki Krakowskiej. Wydanie jubileuszowe z okazji 50-lecia Politechniki Krakowskiej (Kraków, 1995), s. 69.

[27] State Archive of Lviv Oblast. Repository 26, Desc. 5, Case 967; Lviv University Archive, Repository
119, Desc. 1, Case 92.

[28] State Archive of Lviv Oblast. Repository 26, Desc. 5, Case 1255; Lviv University Archive, Repository 119, Desc. 5, Case 330

[29] Vasyl' Milijanchuk. Do 100-richchja vid dnja narodzhennja, compiled by O. Popel (Jevrosvit, Lviv, 2005).

[30] State Archive of Lviv Oblast. Repository 26, Desc. 4, Case 614; Lviv University Archive, Repository 119, Desc. 1, Case 201.

[31] Israel State Archive, 11.1/6-114.

[32] State Archive of Lviv Oblast. Repository 26, Desc. 3, Cases 488, 488, 615.

[33] WorldCat, http://www.worldcat.org.

[34] Xiè Yǒng, Ėrshíyī shìjì pínglùn [The Twenty-First Century Review] 89, 50 (2005).

[35] B. Simon, Ann. Math. Second Ser. 97, 247 (1973).

\title{
БІБЛІОГРАФІЯ КАФЕДРИ ТЕОРЕТИЧНОЇ ФІЗИКИ ЛЬВІВСЬКОГО УНІВЕРСИТЕТУ В 1914-1939 РОКАХ
}

\author{
Андрій Ровенчак \\ Кафедра теоретичної фізики, Львівсъкий національний університет імені Івана Франка, \\ вул. Драгоманова, 12, Львів, 79005, Україна
}

У статті проаналізовано історію кафедри теоретичної фізики Львівського університету протягом 19141939 років. Наведено повний відомий на сьогодні перелік праць кафедри за цей період. Подано короткі біографічні відомості про осіб, які працювали на кафедрі в ці роки. 